\title{
AÇÃO RESCISÓRIA: O cabimento da ação rescisória nos juizados especiais federais frente à Constituição Federal de 1988
}

\author{
Daniele Carvalho Carlotto ${ }^{1}$
}

\begin{abstract}
RESUMO: O presente trabalho tem como objetivos: conceituar coisa julgada e ação rescisória; analisar as hipóteses de cabimento e aplicação desta quando houver decisão proferida por Juiz Federal investido de jurisdição em Juizado Especial Federal; bem como examinar os princípios constitucionais do devido processo legal e da inafastabilidade do controle jurisdicional. Da mesma forma, verificar a questão da omissão da Lei $n^{\circ} 10.259$, de 12 de julho de 2001, a qual, por sua vez, leva à aplicação subsidiária da Lei $\mathrm{n}^{\circ}$ 9.099, de 26 de setembro de 1995, no que tange à proibição do seu art. 59, para proposição da rescisória. Para tanto, realizou-se uma análise do que deve prevalecer entre ditames constitucionais e lei infraconstitucional. Visou-se realizar uma releitura das leis, a partir da supremacia constitucional, a fim de proporcionar a possibilidade de ajuizamento da rescisória.
\end{abstract}

PALAVRAS-CHAVE: coisa julgada - ação rescisória - Constituição Federal - Juizados Especiais Cíveis e Federais.

\section{Rescissory Action}

\begin{abstract}
The present work has as objective: judge tried thing and the rescissory action analyze the cabyment hypotheses and its aplication when there is Federal Special Court as well as to examine the constitutional principles due how legal process and do not removel jurisdictional control. In the same way verify a Law omission matter $\mathrm{n}^{\mathrm{o}} 10.259$ of July 12, 2001 one which then carries to the subsidiary application of the Law $n^{\circ}$ 9.099, of September 26, 1995 none that tolls to the prohibition your article 59 for preposition of rescissory. For so much it accomplished an analysis that should prevail input constitutional admonition and infraconstitucional law. It aimed to realize read again the laws one leave of the constitutional supremacy an end of providing the possibility of the interposition of the rescissory.

KEY-WORDS: tried thing - rescissory action - Federal Constitution - Civil Special and Federal Courts.
\end{abstract}

\section{INTRODUÇÃO}

A sentença que analisa o mérito da ação com trânsito em julgado material proferida contra texto da Constituição Federal de 1988 e disposição da lei, ou que viole direito expresso, poderá ser desconstituída pela ação rescisória. Esta se traduz por uma ação autônoma de impugnação, constitutiva negativa ou desconstitutiva de direito, destinada a rescindir sentença ou acórdão transitados em julgado. $\mathrm{O}$ rol de hipóteses para o ensejo de tal ação está taxativamente elencado no art. 485 e incisos, do Código de Processo Civil.

A Lei $n^{\circ} 10.259 / 01$, referente aos Juizados Especiais Federais, é omissa quanto à possibilidade de propositura da ação rescisória. Então, utiliza-se, subsidiariamente, o

\footnotetext{
${ }^{1}$ Graduada em Direito. Estudante - Centro Universitário Franciscano

ISSN - 1981-3694

(C) 2007. Departamento de Direito da UFSM. Todos os direitos reservados.
} 
art. 59 da Lei $\mathrm{n}^{\circ}$ 9.099/95, que inadmite a propositura da rescisória nas causas sujeitas ao procedimento dos juizados, sob justificativa destes objetivarem um rito mais célere. Destarte, questiona-se sobre a proibição trazida pelo art. 59 da Lei $n^{\circ} 9.099 / 95$, se é ou não constitucional, seja por inobservar princípios constitucionalmente positivados, seja por ir contra o próprio texto da Carta Maior. E, para dar tal enfoque ao tema, mister verificar a possibilidade de relativização da coisa julgada material.

Pretende-se verificar a discussão a respeito da (im)possibilidade de rescindir sentença prolatada por magistrado federal em sede de Juizado Especial Federal (JEF), frente à proibição do art. 59 da Lei $n^{\circ}$ 9.099/95 e à omissão da Lei $n^{\circ} 10.259 / 01$, a fim de sopesar a supremacia e efetividade constitucional no tocante a seus princípios e regras. Portanto, parte-se da hipótese de que a coisa julgada não constitui uma garantia absoluta, devendo ser compreendida à luz dos princípios constitucionais vigentes, especialmente, o do devido processo legal e o do acesso à justiça, a fim de encontrar o desejado equilíbrio entre a segurança jurídica e a justiça das decisões.

\section{COISA JULGADA E AÇÃO RESCISÓRIA}

O instituto ligado ao fim do processo e à imutabilidade do ato decisório, visando gerar segurança jurídica às partes consiste na coisa julgada. Há duas espécies de coisa julgada: a formal e a material. Esta só se produz quando tratar de sentença de mérito, cuja decisão vai além dos limites do processo, ou seja, não se pode mais interferir sobre o já decidido em nenhuma outra ação, pois a determinada sentença judicial passa a ter autoridade de coisa julgada (ALMEIDA; TALAMINI; WAMBIER, 2002).

A coisa julgada formal significa a impossibilidade de impugnar sentença ou acórdão dentro do processo em que foi proferida, logo, os efeitos são endoprocessuais, podendo-se repropor a ação com as mesmas partes e pedido. Ocorrerá tanto na hipótese de uma sentença processual quanto de mérito. Já a coisa julgada material é a qualidade de imutabilidade do dispositivo da sentença de mérito, tornando-se indiscutível fora daquele processo, com efeitos extraprocessuais (FREIRE, 2005).

Na coisa julgada material, a decisão vai além dos limites do processo, não sendo mais possível interferir sobre o já decidido em nenhuma outra ação. A decisão judicial passa a ter autoridade de coisa julgada, com efeito de lei entre as partes, a exemplo das sentenças de mérito transitadas em julgado, ou seja, não se admite mais recursos ordinário ou extraordinário (ALMEIDA; TALAMINI; WAMBIER, 2002). 
Da mesma forma, José Maria Rosa Tesheiner (2001), define o instituto da coisa julgada material como o caráter de imutabilidade do conteúdo da sentença no mesmo ou noutro processo, impondo-se a quem quer que seja: autoridade judicial, administrativa ou mesmo legislativa. Para ocorrer a coisa julgada material é preciso que o conteúdo da sentença não possa ser desprezado ou modificado, mesmo em outra ação, exceto a rescisória.

O instituto da coisa julgada tem o condão de fazer preponderar a segurança das relações sociais e jurídicas sobre a qualidade e certeza do julgado. Porém, mesmo se dominante tal opção, não representa uma alternativa usada incondicionalmente. No ordenamento jurídico brasileiro, há situações excepcionais autorizadoras da reapreciação da sentença imutável: a ação rescisória, um dos instrumentos destinados a obter a anulação/desconstituição da coisa julgada formada, para possibilitar a revisão do julgamento (MARINONI; ARENHART, 2001). Conforme Tucci (2001):

Nos sistemas processuais contemporâneos, a sentença de mérito, mesmo depois de adquirir a autoridade de coisa julgada material, pode ainda ser revogada em hipóteses excepcionais. Costuma-se justificar esta técnica na necessidade de prevalência de um interesse que transcende aquele das partes à realização de justiça, uma vez que a decisão definitiva poderá apresentar um vício tão nocivo à ordem pública que propicia a sua revogação inclusive após ter-se operado a preclusão dos prazos para a interposição de quaisquer recursos. Os mecanismos processuais instituídos para esse fim são tradicionalmente de duas espécies - ação autônoma ou recurso - ambos considerados de natureza especial em razão de seu escopo, que se destaca das vias ordinárias de impugnação e supera o da generalidade das ações (TUCCI, 2001, p. 257).

Tão logo, a coisa julgada torna-se efetivamente imutável após o decurso do biênio decadencial, sendo o respectivo prazo para o ajuizamento da ação rescisória, contado do trânsito em julgado da decisão, conforme fixa o art. 495 do Código de Processo Civil, a partir do qual dá-se o fenômeno conhecido como coisa soberanamente julgada (TEIXEIRA apud NERY JUNIOR; WAMBIER, 2002).

Contudo, de acordo com a Constituição Federal de 1988, uma lei posterior com finalidade de reger fatos passados, de maneira alguma, pode prejudicar a coisa julgada, ou seja, transitada em julgado a sentença que criou determinada obrigação, nova lei que desonere a obrigação não tem nenhuma influência sobre o caso julgado. Diferentemente disso, não ofende a Constituição a revisão da sentença por fato superveniente à coisa 
julgada, pois inexiste a retroatividade quando se rescinde a sentença, acarretando novo julgamento (TESHEINER, 2001).

Conforme Nery Junior (2004-a):

A sentença de mérito transitada em julgado que tiver sido prolatada contra texto da CF e da lei pode ser desconstituída pela ação rescisória. A sentença de mérito transitada em julgado que seja injusta faz, inexoravelmente, coisa julgada material, sendo insuscetivel de impugnação por ação rescisória, por mais grave que possa ter sido a injustiça [...]. Somente a sentença inconstitucional ou ilegal, tendo sido acobertada pela coisa julgada material, pode ser desconstituída pela via da ação rescisória (NERY JUNIOR, 2004-a, p. 513-514).

De acordo com a Súmula 514 do STF, admite-se, igualmente, a rescisória contra sentença transitada em julgado, ainda que não se tenha esgotado todos os recursos, bastando o trânsito em julgado da decisão. Simplesmente, depois de proferida a sentença ou decisão, abre-se o prazo para a interposição de possíveis recursos, mas as partes optam por não usá-los, terminando o período para recorrer (DIDIER, 2005).

Não se pode confundir ação rescisória com recurso. Para tanto, ensina o processualista Ovídio Araújo Baptista da Silva (2002) que há dois elementos decisivos para a caracterização dos recursos: são formas de atacar/impugnar o ato jurisdicional integrante da mesma relação processual; e servem como remédio voluntário, a ser utilizado pelas partes.

A rescisória consiste em um remédio processual com finalidade de equilibrar dois ideais opostos de suma importância no sistema processual brasileiro: a garantia da estabilidade social, adquirida por meio da coisa julgada, e o fim das injustiças pela eliminação dos vícios tidos como graves pelo legislador. As taxativas hipóteses de cabimento dessa ação desconstitutiva estão positivadas no Código de Processo Civil, em seu artigo $485^{2}$ (DINAMARCO, 2004).

\footnotetext{
${ }^{2}$ Art 485. A sentença de mérito, transitada em julgado, pode ser rescindida quando:

I - se verificar que foi dada por prevaricação, concussão ou corrupção do juiz;

II - proferida por juiz impedido ou absolutamente incompetente;

III - resultar de dolo da parte vencedora em detrimento da parte vencida, ou de colusão entre as partes, a fim de fraudar a lei;

IV - ofender a coisa julgada;

V - violar literal disposição de lei;

VI - se fundar em prova, cuja falsidade tenha sido apurada em processo criminal, ou seja, provada na própria ação rescisória;

VII - depois da sentença, o autor obtiver documento novo, cuja existência ignorava, ou de que não pôde fazer uso, capaz, por si só, de lhe assegurar pronunciamento favorável;
} 
Segundo Teresa Arruda Alvim Wambier (2002), também estão sujeitas à ação rescisória sentenças nulas e "meramente rescindíveis", isto é, em si mesmas não possuem nenhum vício nem provêm de processos contidos de vícios a ponto de contaminá-las, a saber, na hipótese de surgir documento novo (art. 485, VII, CPC).

\subsection{Juizados Especiais: omissão da Lei $n^{0} 10.259 / 01$ e vedação do art. 59, da Lei $n^{0}$ 9.099/95}

A Lei n ${ }^{\circ}$ 10.259, de 12 de julho de 2001, referente aos Juizados Especiais Cíveis no âmbito da Justiça Federal, nada fala quanto à possibilidade de as partes proporem a ação rescisória. No seu art. $1^{\circ}$, há previsão dispondo que, naquilo que não conflitar com a referida lei, aplicar-se-á o disposto na Lei $\mathrm{n}^{\circ}$ 9.099, de 26 de setembro de 1995, dos Juizados Especiais Cíveis. É atribuída tal regra para a omissão da Lei 10.259/01 sobre o cabimento da rescisória nos Juizados Federais. Então, utiliza-se, subsidiariamente, o art. 59, da Lei $\mathrm{n}^{\text {0 }}$ 9.099/95 que veda o ajuizamento da rescisória em âmbito de Juizados Especiais.

Historicamente, os Juizados Especiais Cíveis forma criados com a intenção de simplificar o rito do processo e acelerar ao máximo a prestação jurisdicional, facilitando, inclusive, o acesso à justiça às classes economicamente desfavorecidas. No início da década de 1980, os juízes, mesmo sem apoio em lei que conferisse força executória às decisões aí tomadas, instituíram a título experimental, órgãos especiais: os chamados conselhos de conciliação e julgamento. Estes eram formados por árbitros, escolhidos dentre bacharéis de direito, sob coordenação de um juiz de direito (FABRÍCIO, 2001).

Conseqüentemente, em 07 de novembro de 1984 foi publicada a Lei $\mathrm{n}^{\circ} 7.244$, dando vida ao Juizado Especial de Pequenas Causas, precursor dos atuais Juizados Especiais Cíveis e Criminais. Superada a Lei $n^{\circ} 7.244 / 84$, os Juizados Especiais instituíram-se pela Lei n. 9.099, de 26 de setembro de 1995, e são competentes para decidir causas em virtude do valor (até quarenta salários mínimos), da matéria (aquelas

VIII - houver fundamento para invalidar confissão, desistência ou transação, em que se baseou a sentença;

IX - fundada em erro de fato, resultante de atos ou de documentos da causa.

$\S 1^{\circ}$ Há erro, quando a sentença admitir um fato inexistente, ou quando considerar inexistente um fato efetivamente ocorrido.

$\S 2^{\circ}$ É indispensável, num como noutro caso, que não tenha havido controvérsia, nem pronunciamento judicial sobre o fato (BRASIL, 2006, p. 430). 
tidas como de menor complexidade) e ainda do julgamento das infrações penais de menor potencial ofensivo (aquelas cuja lei comine pena máxima não superior a dois anos).

O processo, nesses juízos, valoriza os critérios/princípios da oralidade, da simplicidade, da informalidade, da economia processual e da celeridade, buscando sempre a possibilidade de conciliação entre as partes (NEGRÃO, 2005).

Tão logo, a Emenda Constitucional n. 22, de 18 de março de 1998, introduziu parágrafo único no art. 98 da Constituição Federal e determinou a criação de Juizados Especiais na Justiça Federal, suprindo a omissão constante na Constituição de 1988, que referira a instalação desses juizados apenas na Justiça Estadual. A partir daí, ficou-se na dependência de legislação ordinária. E, nesse contexto, nasceu a idéia dos Juizados Especiais Federais, surgindo, então a Lei no 10.259, de 12 de julho de 2001. Tais órgãos jurisdicionais foram criados com o objetivo de eliminar ou pelo menos diminuir alguns dos obstáculos ao efetivo acesso à justiça (TOURINHO NETO; FIGUEIRA JÚNIOR, 2002).

Conforme a explanação alhures acerca da rescisória, cabe fazer uma análise quanto à possibilidade de seu cabimento nos processos sujeitos à tramitação nos Juizados Especiais Federais. Para tanto, reporta-se à Lei no ${ }^{\circ} 10.259 / 01$, a qual é omissa a respeito da propositura de ação rescisória perante o Juizado Federal. Nesse caso, no que com ela não conflitar, será aplicado o disposto no art. 59 da Lei n $^{\circ} 9.099 / 95$, o qual inadmite a rescisória nas causas sujeitas ao procedimento instituído por esta lei.

O princípio da celeridade, norteador dos Juizados Especiais, constitui uma das justificativas pela qual se embasa a vedação para a ação rescisória, já que prioriza a menor complexidade e efetividade do rito processual. No entanto, não basta apoiar-se somente na segurança de uma prestação jurídica rápida, mas, sobretudo, gerar uma prestação judicial eficiente (CHIMENTI, 2005).

Desse modo, torna-se perfeitamente possível dar prioridade à rapidez e, ao mesmo tempo, assegurar a justiça, no sentido de permitir ser o vencedor quem, efetivamente, teve razão, evitando, no processo, a formação de vantagem indevida (CARNEIRO, 2000). Então, a celeridade deve agir em consonância com os princípios constitucionais protetores do acusado, pois a obediência a estes leva à democratização da administração da justiça (TOURINHO NETO; FIGUEIRA JUNIOR, 2002). Assim, faz-se necessário analisar a hierarquia principiológica e normativa do plano constitucional, imposta pelo ordenamento jurídico brasileiro. 
2.1.1 Supremacia dos princípios e regras constitucionais no ordenamento jurídico brasileiro

Os princípios constituem espécie de normas e estabelecem um fim a ser atingido. Eles se traduzem como mandamentos de otimização, ou seja, ordenam que algo seja cumprido na sua maior medida possível, de acordo com as circunstâncias fáticas e jurídicas existentes (ÁVILA, 2006). Em sentido geral, sob a visão de Silva (2003):

\section{[...] princípios revelam o conjunto de regras ou preceitos, que se fixam para servir de norma a toda espécie de ação jurídica, traçando, assim, a conduta a ser tida em qualquer operação jurídica. Desse modo, exprimem sentido mais relevante que o da própria norma ou regra jurídica [...] (SILVA, 2003, p. 1095).}

No sistema jurídico brasileiro, os princípios constitucionais devem preponderar sobre as regras infraconstitucionais. Assim, eles presidem as relações jurídicas, até porque a vulneração de um princípio pode implicar lesão mais grave do que aquela resultante de violação de uma regra (ARMELIN, 2004).

O intérprete deve buscar a aplicação da lei ao caso concreto, tendo como pressuposto o exame da Constituição Federal. Após, a consulta deve ser feita na legislação infraconstitucional. Caso esteja em desacordo com o texto constitucional, não pode, obviamente, ser aplicada. Comprovada a divergência: se a norma legal tiver sido editada antes da $\mathrm{CF} / 88$, terá ocorrido o fenômeno da não recepção pela nova ordem, sendo a lei com ela incompatível; se a norma for editada após o advento da Magna Carta, será inconstitucional e não poderá ser aplicada para a solução do caso concreto. Esta consiste na razão pela qual é devido conhecer e aplicar os preceitos constitucionais em toda a sua extensão, independente do ramo do direito infraconstitucional a ser examinado (NERY JUNIOR, 2004-b). Em vista de tal supremacia, os preceitos infraconstitucionais devem agir em conformidade com os ditames da Carta Maior.

A vedação expressa no art. 59 da Lei n ${ }^{\circ} 9.099 / 95$ pode se dar em razão do fato de a CF/88 ser anterior à criação desta Lei (1995), mas isto não justifica a desatenção do legislador ao estabelecer os parâmetros legais à criação de novas regras, nem inobservar os ditames da Carta da República. Para Cintra, Grinover e Dinamarco (2004):

[...] haverá no ordenamento jurídico, ainda que latente e inexpressa, uma regra para disciplinar cada possível situação ou conflito entre pessoas. $O$ mesmo não 
acontece com a lei; por mais imaginativo e previdente que fosse o legislador, jamais conseguiria cobrir através dela todas as situações que a multifária riqueza da vida social, nas suas constantes mutações, poderá provocar. Assim, na busca da norma jurídica pertinente às situações concretas ocorrentes na sociedade, muitas vezes será constatada a inexistência de lei incidente: a situação não fora prevista e, portanto, não fora regulada pelo legislador. Mas, evidentemente, não se pode tolerar a permanência de situações não definidas perante o direito, tornando-se então necessário preencher a lacuna da lei [...]. O preenchimento das lacunas da lei faz-se através da analogia e dos princípios gerais do direito [...] (CINTRA; GRINOVER; DINAMARCO, 2004, p. 101103).

Assim, a proibição de propor a rescisória nos Juizados Federais impossibilitaria a desconstituição das suas decisões definitivas exaradas. Por outro lado, faz-se uma interpretação aprofundada e sistemática de dispositivos legais e constitucionais, podendo formular juízo diverso. Desde pronto, incumbe destacar uma discussão, apenas doutrinária, sobre uma possível inconstitucionalidade do artigo 59, da Lei ${ }^{\circ}$ 9.099/95, quando confrontado com a $\mathrm{CF} / 88$ e seus princípios. Entende-se que para solucionar conflitos entre lei infraconstitucional (especial) e norma constitucional, a última prevalecerá, por ser superior a qualquer outra regra do sistema brasileiro. Justamente, não haveria motivos para cumprir determinada proibição de lei hierarquicamente inferior, já que a Constituição, genericamente, autoriza o ajuizamento da ação, funcionando como um permissivo legal, quando trata da delimitação de competência dos juízes federais para processar e julgar a rescisória. Contudo, a vedação do art. 59 não encontra respaldo na Magna Carta.

Estrutura-se tal entendimento porque a Lei Suprema consiste em fundamento de validade de lei, a fim de proporcionar garantias essenciais através de uma justiça eficaz. Os juízes, como intérpretes do direito, devem verificar a legitimidade da lei, jamais a aplicando cegamente, no intuito de evitar uma decisão injusta decorrente de legislação arbitrária. Enfim, prima-se pela utilização do direito à luz da $\mathrm{CF}$, por estar no ápice do ordenamento jurídico brasileiro e, portanto, ser hierarquicamente superior às demais formas legais (CAMBI, 2001).

2.1.2 Os princípios constitucionais do devido processo legal e da inafastabilidade do controle jurisdicional

O impedimento da rescisória no Juizado Federal ocasiona uma violação, além dos dispositivos referidos alhures, dos princípios constitucionais do devido processo 
legal, elencado no art. 5o, LIV, e o da inafastabilidade do controle jurisdicional, conhecido também como direito de ação ou acesso à justiça, presente no art. $5^{\circ}, \mathrm{XXXV}$, ambos da Constituição Federal de 1988.

Nesse contexto, o princípio da inafastabilidade compreende-se como garantia do direito de ação e do acesso à justiça, através da realização concreta dos direitos e de procedimentos destinados a conferir ao jurisdicionado a tutela adequada, tempestiva e efetiva (MARINONI; ARENHART, 2000).

$\mathrm{O}$ acesso à justiça, também conhecido como direito de ação e/ou princípio da inafastabilidade do controle jurisdicional, constitui-se na oferta constitucional e legal dos princípios e garantias fundamentais e de direitos individuais porventura violados (CINTRA; GRINOVER; DINAMARCO, 2004).

Na visão de Rui Portanova (2003), o acesso à justiça, garantidor do pleno acesso à ordem jurídica justa, é traduzido por um princípio geral, pré-processual e até supraconstitucional, porque informa os demais princípios ligados à ação e à defesa, como é o caso do direito de ação. Por meio desta, o Estado disponibilizou ao cidadão a faculdade de utilizar o Poder Judiciário para efetivar os direitos individuais e sociais.

O direito de ação trata-se de um direito público subjetivo exercitável, ou seja, todos podem obter do Poder Judiciário a tutela jurisdicional adequada (NERY JUNIOR, 2004-b). Nos ditames de Oliveira (2004):

[...] não basta apenas abrir a porta de entrada do Poder Judiciário, mas prestar jurisdição tanto quanto possível, eficiente, efetiva e justa, mediante um processo sem dilações ou formalismos excessivos. Exatamente a perspectiva constitucional do processo veio a contribuir para afastar o processo das construções conceituais e meramente técnicas e inseri-lo na realidade política e social (OLIVEIRA, 2004, p. 18).

O autor Paulo Cezar Pinheiro Carneiro (2000), cita o princípio da proporcionalidade como um princípio informador do acesso à justiça. Quando o julgador precisa decidir alguma questão controvertida, deverá escolher o caminho mais adequado para definir o dilema, adotando o critério razoável da proporcionalidade. Deve ser garantida a efetividade do processo, do bem da vida, em disputa com o menor sacrifício possível para as partes.

$\mathrm{Na} C F / 88$ não há adoção expressa do princípio da proporcionalidade, porém está implícito nos seus dispositivos, demonstrando, assim, não ser absoluto o exercício dos direitos (SILVA, 2003). Nelson Nery Junior (2004-b) denota ser aparentemente 
inconstitucional a norma autorizadora da modificação da coisa julgada pela ação rescisória. Porém, admite existir a previsão legal da rescisória como conseqüência da incidência do princípio constitucional da proporcionalidade, em face da extrema gravidade de uma sentença com vícios. Logo, a rescisória, destinada a modificar a coisa julgada, é constitucional, quando exercida nos limites do art. 485 do CPC, no prazo de dois anos.

O devido processo legal, do qual decorrem os diversos princípios do processo reconhecidos pela Carta Suprema, consiste em um dos mais importantes princípios do direito processual e constitucional. Vislumbra, inclusive, a garantia de uma ação justa, adequada, com regras racionais e razoáveis (MACHADO, 2001). Então, há uma diferença muito tênue entre os princípios da inafastabilidade e devido processo, pois se baseiam em processos sem vícios e/ou justos, com objetivos semelhantes traçados pela Constituição. Para Bondioli (2004):

[...] a conciliação entre princípios, garantias e valores que de alguma forma se vinculam a questão do fato superveniente passa por uma conjugação do acesso à justiça e da utilidade das decisões judiciais com o devido processo legal, o contraditório, a ampla defesa e até a boa-fé das partes. Ao tempo em que o juiz deve estar atento às mutações fático-jurídicas para bem e eficientemente julgar, deve ele tomar toda a cautela para a inserção de eventos ulteriores à estabilização da demanda nas suas razões de decidir, para que tal nunca seja motivo de surpresas para as partes, não dê margem a manobras desleais destas e sempre respeite o máximo possível o devido processo legal, o contraditório e ampla defesa (BONDIOLI, 2004, p. 426).

Miguel Reale (1998) retrata serem os princípios utilizados como garantias e certezas referentes a um sistema de conceitos relativos à proporção e relevância que possuem na realidade, pois constituem-se como verdades ou juízos fundamentais.

\subsubsection{A (in)constitucionalidade do art. 59, da Lei $n^{o}$ 9.099/95 e posicionamentos} divergentes

Em vista do exposto, torna-se preciso fazer uma relação, de modo a comparar princípios e dispositivos da CF com o art. 59 da Lei 9.099/95, reportando-se à sua vedação no que tange à rescisória, para, conseqüentemente, obter um resultado satisfatório sobre a sua (im)possibilidade de ajuizamento no Juizado Federal. Por isto, a seguir serão explanadas algumas opiniões divergentes. Para Souza (2001): 
[...] o art. 59 da Lei $n^{o}$ 9.099/95 é de total inconstitucionalidade, por violar frontalmente o Estado Democrático de Direito, previsto no art. $1^{\circ}$ da $\mathrm{CF} / 88$, uma vez que o Estado Democrático de Direito não pode proteger, estimular ou chancelar o estelionato judicial e o enriquecimento ilícito dos seus agentes, semeando a insegurança jurídica, em detrimento do patrimônio e dos bens dos cidadãos (SOUZA, 2001, sp).

No mesmo sentido, Joel Dias Figueira Júnior, Maurício Antonio Ribeiro Lopes (2000) e Fernando da Costa Tourinho Neto (2002), entendem não haver razões plausíveis para excluir a ação rescisória do elenco dos meios de impugnação contra as decisões proferidas nos Juizados, pois os Juízes de primeiro grau ou os Colegiados Recursais dos Juizados poderão incidir em qualquer das hipóteses figuradas no art. 485 do CPC. Inclusive, propõem a reforma da lei para modificar a redação do art. 59.

Fernando da Costa Tourinho Neto e Joel Dias figueira Júnior (2002), contrários à redação do art. 59, citam o esboço do anteprojeto de lei da Associação dos Juízes Federais (AJUFE), que previa expressamente, no art. 49, Capítulo VII, a competência específica da Turma Recursal para tratar do processo e julgamento das ações rescisórias e das revisões criminais de seus próprios julgados, bem como das sentenças de mérito proferidas pelos Juizados Especiais Federais. Entretanto, o legislador deixou de positivar, em Lei Especial, o artigo supra citado, ficando apenas em nível de projeto.

Alex Pedrozzo Boeira (2005) afirma que em estrita observância aos ditames dos artigos da CF/88: 108 (I, b) e 98 (I), deve ser firmada a competência para o processo e julgamento da ação rescisória contra decisão proferida por juiz federal, investido de jurisdição em Juizado Especial Federal.

Ao atribuir a competência para julgar a rescisória, o autor Vladimir Souza Carvalho (2005) infere ser a turma recursal o órgão competente para decidi-la quando as sentenças são proferidas por magistrado federal investido na jurisdição do Juizado Federal. Logo, acaba deixando implícita a admissão da mesma ação, no momento em que opina pela atribuição de quem irá julgá-la, quando originadas de Juizados Especiais.

Nesse passo, Pablo Drews Bittencourt Costa (2001) critica o conteúdo do art. 59 da Lei $n^{\circ}$ 9.099/95:

Não deve o Poder Judiciário, a quem cabe a precípua função de proteção aos direitos do cidadão, ir de encontro à sua atribuição constitucional. Todavia, por ser composto de pessoas [...] falíveis, há que se garantir meios para que os erros porventura cometidos sejam corrigidos, não vindo a se perpetuar (COSTA, 2001, sp). 
Tiago Ivo Odon (2005), manifesta-se contra a vedação da rescisória em Juizado Especial, pela justificativa de ofender o princípio do devido processo legal, conquistado pela civilização ocidental e consagrado no art. $5^{\circ}$, LIV da $\mathrm{CF}$, bem como o direito constitucional de ampla defesa (art. 5, LV). Retrata que a Lei n ${ }^{\circ}$ 9.099/95 abre espaço para o totalitarismo e a arbitrariedade dos juízes e deixa o cidadão desprovido de meios para se opor à decisão de mérito transitada em julgado.

Felippe Borring Rocha (2002), reconhecendo ser o primeiro caso no ordenamento jurídico em que se veda a ação impugnativa desconstitutiva em juízo de mérito, nos Juizados Federais, sustenta tal fato como um absurdo, alegando ser inimaginável a aceitação de uma sentença proferida por juiz impedido, suspeito ou corrupto, que ofenda a coisa julgada, a lei, enfim. Opina pelo cabimento desta ação, porém, defende a diminuição do prazo para a propositura, em virtude do princípio da celeridade atribuído ao rito dos Juizados.

Incentiva Cândido Rangel Dinamarco (2005) pela não aplicação do art. 59 da Lei ${ }^{\circ}$ 9.099/95 e, por via reflexa, admite o cabimento da rescisória.

Reza Dinamarco (2004):

A ação rescisória é a última de todas as esperanças pela restauração da ordem jurídica, quando violada com a chancela da autoridade da coisa julgada material [...]. Não fora a ação rescisória, as injustiças acobertadas pela coisa julgada e pela sua eficácia preclusiva restariam eternamente imunes e permaneceriam por todo o sempre. Por isso é que se diz que ela se caracteriza como um instrumento da justiça, para o equilíbrio daquele binômio de exigências existentes no processo. A celeridade no decidir e a firmeza das decisões são valores a preservar (prazos, preclusões, coisa julgada material), mas não se descuida dos erros que podem ter sido cometidos e injustiças eventualmente perpetradas. A excepcionalidade da ação rescisória no sistema processual não pode e não deve servir de motivo ou pretexto para excessivas limitações (DINAMARCO, 2004, p. 24-25).

Assevera Edilson Pereira Nobre Júnior (2002) ser contrário à proibição da rescisória em JEF. Este, apesar de primar pela celeridade dos seus processos, não pode autorizar a perpetuação de um litígio provido de erros, vícios ou nulidades.

De outra banda, Rodrigo da Cunha Lima Freire e Fredie Didier (2005), a contrário senso, afirmam, pelo teor da Lei $\mathrm{n}^{\circ}$ 9.099/95, art. 59, não ser possível o ajuizamento de ação rescisória em sede de Juizados Especiais. Igualmente, é referida por Maria Lúcia Luz Leiria (1990), a manifestação do Desembargador Federal Celso 
Kipper, ao prolatar voto a favor da proibição da rescisória em Juizados Especiais, tendo em vista que sua manutenção configurara afronta aos princípios regentes do microssistema, sobretudo da economia processual e da celeridade, e, por conseguinte, afastaria o objetivo perseguido pelo legislador, qual seja, o de limitar as dilações indevidas no processo.

Sustenta Douglas Fischer (2005) pela impossibilidade de rescindir sentença dos Juizados Federais, conforme positivado na regra do art. 59 da Lei $n^{\circ}$ 9.099/95, se respeitado os princípios constitucionais, especialmente os do devido processo legal, contraditório e ampla defesa.

A justificativa para a inaplicabilidade do artigo citado está atrelada ao fato de se querer preservar o rito simplificado e célere dos Juizados, na tentativa de aproximar a sociedade à jurisdição. Admitir o processamento da ação referida nos Juizados Especiais seria tornar inócuo todo um sistema construído com objetivos de prestar uma justiça célere e menos formal.

\subsubsection{Escolha e defesa do posicionamento adotado}

Para uma implantação bem sucedida de Juizados Especiais na Justiça Federal, seria necessária uma estrutura administrativa e funcional a fim de suportar o ritmo de tramitação dos processos nas respectivas varas. Precisa-se de juristas que sejam, antes de tudo, seres humanos preocupados com as pessoas comuns e com a garantia de seus direitos. O objetivo da criação dos Juizados Especiais Federais está em tornar a justiça mais acessível àqueles que necessitam e cujos meios de atingi-la são bastante precários. Sua criação traz ínsita uma preocupação de democratização do acesso ao Poder Judiciário Federal, e, portanto, consubstancia-se em importante expressão de Justiça Social (TEIXEIRA, 2001). Algumas jurisprudências cuidam do tema em questão:

PROCESSO CIVIL. QUESTÃO DE ORDEM. AÇÃO RESCISÓRIA. SENTENÇA DO JEF. COMPETÊNCIA. Tratando-se de ação rescisória para desconstituir sentença proferida por juiz federal investido de jurisdição do Juizado Especial, a competência para seu exame é atribuída à Turma Recursal (BRASIL, 2004-a, sp).

PROCESSO CIVIL. AÇÃO RESCISÓRIA. JEF. DECISÃO DA TURMA RECURSAL. COMPETÊNCIA. Cuidando-se de rescisória que ataca acórdão proferido pelo colegiado revisor do Juizado Especial Federal, a competência para seu exame é atribuída ao próprio órgão. Aplicação analógica de 
precedente do colendo STJ que, em se tratando da Justiça Estadual, decidiu não haver vinculação entre o segundo grau do Juízo Especializado e o Tribunal local (BRASIL, 2004-b, sp).

As jurisprudências expostas tratam do conflito de competência para julgamento da rescisória, o que não é o objeto do tema em estudo, mas, a pretensão com essa análise consiste em salientar que, se há discussão a respeito da competência para julgamento da ação, é porque, de certa forma, exista possibilidade de admissão da rescisória no âmbito dos Juizados Especiais Federais.

No entanto, na prática ocorre diferente e isto é demonstrado pelas interpretações diversas proferidas nos julgamentos da Turma Recursal da Quarta Região do Rio Grande do Sul. Entendem não ser cabível ação rescisória em sede de Juizado Especial, pela vedação contida no art. 59 da Lei 9.099/95, bem como pelo fato de ir de encontro aos princípios norteadores dos Juizados Especiais. Assim, afetaria o espírito do Juizado Especial de simplificar os ritos e as formas. Acrescentam também que a não aplicabilidade do art. 59 nos Juizados Especiais Federais de forma alguma restringe o acesso à jurisdição, inocorrendo violação aos princípios contidos no art. $5^{\circ}, \mathrm{XXXV}$, LIV, LV, e art. 195, $\S 5^{\circ}$, da CF/88 (BRASIL, 2005, sp).

De outra senda, sob o prisma constitucional, não haveria motivos para vedar a rescisória no JEF. Entretanto, nota-se, conseqüentemente, a elevada inaplicabilidade e inefetividade da Carta Magna quanto a seus dispositivos e princípios fundamentais no real ordenamento jurídico brasileiro. Talvez o legislador aplique essencialmente o positivado em lei infraconstitucional e deixe de lado o seu poder de livre convencimento e os critérios de razoabilidade. Isto é contrário à situação concreta das partes, ao acesso à justiça, ao devido processo, dentre outros princípios da Carta Maior.

Ademais, a economia processual deve ser sempre examinada para haver um equilíbrio entre segurança e rapidez. Nos casos em que a celeridade importar em grave desgaste da segurança, há que se afastar a primeira, para evitar-se que, em nome da economia processual, sejam permitidos verdadeiros abusos de direito, com subversão dos próprios critérios de justiça (TOSTES; CARVALHO, 1998).

Cândido Rangel Dinamarco (2005) assevera que, se a sentença transitada em julgado tiver feito mal a alguma das partes, a ação rescisória a emendará. Quando o vício ou a nulidade forem excepcionalmente graves e enumerados pelo art. 485 do CPC, fica justificada a quebra da coisa julgada, apesar do valor tido por ela. 
Portanto, nos dias atuais, é, ainda, possível reconhecer a supremacia da Constituição como expressão da vontade soberana de um povo, servindo de base e fonte de validade às demais normas do ordenamento (FERRARI, 2001).

Com todo o exposto, acredito ser cabível a rescisória como remédio jurídico para desconstituir decisão definitiva de mérito, transitada em julgado, proferida em processos de competência dos Juizados Especiais Federais, desde que seja verificada alguma das hipóteses do art. 485, CPC.

\section{CONSIDERAÇÕES FINAIS}

O objetivo primordial da ação rescisória compreende, além de atacar a coisa julgada material, fazer cumprir a efetividade do devido processo legal, com vista a proporcionar o direito da parte de ter seu pedido apreciado pelo órgão judiciário. A rescisória significa, formalmente, um instituto de direito que busca cindir uma decisão de mérito proferida em relação jurídica processual contaminada por vício, nulidade, erros, dentre outros. Assim, não sendo absoluto o princípio da imutabilidade da coisa julgada, ela poderá ser questionada quando ofender a Constituição, pois se deve ter em mente que o processo adequado será aquele que confira ao jurisdicionado o acesso à ordem jurídica justa e legitimidade constitucional.

O sistema jurídico brasileiro, em razão da própria segurança jurídica, carece de uma regra positivada no intuito de permitir ao julgador afastar a coisa julgada inconstitucional, ou seja, balancear direitos conflitantes e dizer, no caso concreto, qual deve prevalecer. A possível solução para o conflito entre a segurança jurídica e demais princípios constitucionais, como o da celeridade processual, está na ponderação destes princípios no caso concreto.

Portanto, os princípios e ditames constitucionais podem ser colocados em prática para garantir a efetividade do Texto Magno. O sistema processual permite o risco de sentença materialmente injusta, desde que atendidos o devido processo legal e as normas processuais constitucionais, já que a coisa julgada material e a segurança jurídica são direitos fundamentais do jurisdicionado. Porém, o direito processual civil brasileiro estabelece circunstâncias nas quais poderá ser desfeito o ato sentencial, o que indica não ser um valor absoluto a imutabilidade da coisa julgada material, frente a outros valores constitucionais com a mesma hierarquia da segurança jurídica. 
De um modo geral, existe uma certa descrença das pessoas no poder judiciário, seja porque este, as partes e os representantes técnicos aceitam as regras do jogo, quanto à suficiência da verdade formal para cimentar o decidido, seja porque o descompasso da verdade real e formal não constitui um fenômeno recorrente. Pode ocorrer de a segurança jurídica ser satisfeita sem que o justo o seja.

O ideal seria a manutenção da segurança sem sacrifício da justiça, resguardada a proporção entre a atuação de um e de outro destes valores, sem se perder de vista a justiça que é o objetivo maior do sistema jurídico. O grau de desequilíbrio de certas decisões infere o critério para o afastamento da imutabilidade da coisa julgada.

A conciliação entre princípios, garantias e valores vinculados à superveniência de acontecimentos jurídicos durante a pendência do processo é um imperativo da boa prestação da atividade jurisdicional. Ignorar o atual estado dos fatos e do direito no momento da prolação da decisão judicial é atentar contra a utilidade dos provimentos e diminuir ou aniquilar sua capacidade de resolver litígios justamente, ou seja, frustrar a pacificação social e o acesso à justiça. Por outro lado, inserir novos aspectos jurídicos no curso do feito traria tumulto à marcha procedimental e poderia prejudicar as garantias político-constitucionais do devido processo legal, do contraditório e da ampla defesa.

À luz da CF/88 e a despeito da proibição do art. 59 da Lei no 9.099/95 em relação à ação rescisória, entende-se possível o seu cabimento perante os Juizados Especiais Federais, caso a sentença transitada em julgado incorra em algum dos casos do art. 485 do CPC. Tão logo, mesmo sendo o princípio da celeridade basilar e informador dos Juizados Especiais Federais, opta-se pelo detrimento da segurança jurídica sobre o rito célere. A interpretação para os conflitos de leis deve ser feita conforme a Carta Maior.

Assim, é necessário dar a maior efetividade para as normas constitucionais, mediante compreensão de sua força jurídica, para possibilitar a identificação de quando darão lugar aos direitos do cidadão.

\section{REFERÊNCIAS BIBLIOGRÁFICAS}

ARMELIN, Donaldo. Flexibilização da Coisa Julgada. In: COSTA, Hélio Rubens Batista Ribeiro; RIBEIRO, José Horácio Halfeld Rezende; DINAMARCO, Pedro da 
Silva (Coords.). Linhas Mestras Do Processo Civil: comemoração dos trinta anos de vigência do CPC. São Paulo: Atlas, 2004.

ÁVILA, Humberto. Teoria dos Princípios: da definição à aplicação dos princípios jurídicos. 5. ed. São Paulo: Malheiros, 2006.

BOEIRA, Alex Pedrozzo. Ação Rescisória de decisão proferida em Juizado Especial Federal: viabilidade e competência para julgamento. Publicação: 16/05/2005. Revista de Doutrina da $\mathbf{4}^{\mathrm{a}}$ Região. Disponível em: <http://www.revistadoutrina.trf4.gov.br/artigos/edicao006/alex_boeira.htm>. Acesso em: 06 mar. 2006.

BONDIOLI, Luis Guilherme Aidar. Fato Superveniente: Conciliação entre Princípios, Garantias e Valores. In: COSTA, Hélio Rubens Batista Ribeiro; RIBEIRO, José Horácio Halfeld Rezende; DINAMARCO, Pedro da Silva (Coords.). Linhas Mestras Do Processo Civil: comemoração dos trinta anos de vigência do CPC. São Paulo: Atlas, 2004.

BRASIL. Código de Processo Civil; Constituição Federal; Vade Mecum. Colaboradores: Antonio Luiz de Toledo Pinto, Márcia Cristina Vaz dos Santos Windt e Lívia Céspedes, São Paulo: Saraiva, 2006.

BRASIL. Tribunal Regional Federal da Quarta Região de Santa Catarina. PROCESSO CIVIL. QUESTÃO DE ORDEM. AÇÃO RESCISÓRIA. SENTENÇA DO JEF. COMPETÊNCIA. Questão de Ordem na Ação Rescisória nº 200404010290612. Partes litigantes: João Carlos Grah e INSS. Relator Desembargador Federal Nylson Paim de Abreu. DJU: 25/08/2004-a. Disponível em <http://www.trf4.gov.br/trf4/processos/pdf_it.php?num_proc_trf4=200404010290612\& seq_fase $=8>$. Acesso em: 31 maio 2006.

BRASIL. Tribunal Regional Federal da Quarta Região do Paraná. PROCESSO CIVIL. AÇÃO RESCISÓRIA. JEF. DECISÃO DA TURMA RECURSAL. COMPETÊNCIA. Questão de Ordem na Ação Rescisória no 200304010154189. Partes litigantes: INSS e Ananias Santos e outros. Relator Desembargador Federal Victor Luiz dos Santos Laus. DJU: 02/06/2004-b. Disponível em: <http://www.trf4.gov.br/trf4/processos/pdf_it.php?num_proc_trf4=200304010154189\& seq_fase $=17 \&$ PHPSESSID $=6 a 755 \mathrm{a} 8 \mathrm{e} 5 \mathrm{bbaa} 47 \mathrm{a} 9 \mathrm{ece} 600 \mathrm{bca} 1 \mathrm{e} 57 \mathrm{~d} 7>$. Acesso em: 31 maio 2006.

BRASIL. Tribunal Regional Federal da Quarta Região do Rio Grande do Sul. Ação Rescisória $\mathrm{n}^{\circ}$ 200571950108780. Partes litigantes: INSS e Olmira Maria de Oliveira. Relator Presidente Hermes Siedler da Conceição Júnior. Publicação: 14/12/2005. Disponível em: <http://www.jfrs.gov.br/servicos/juris/votopes/200571950108780229750.htm>. Acesso em: 31 maio 2006.

CAMBI, Eduardo. Direito Constitucional à Prova no Processo Civil. São Paulo: Revista dos Tribunais, 2001. 
CARNEIRO, Paulo Cezar Pinheiro. Acesso à Justiça: juizados especiais cíveis e ação civil pública: uma nova sistematização da teoria geral do processo. Rio de Janeiro: Forense, 2000.

CARVAlHO, Vladimir Souza. Competência da Justiça Federal. 6. ed. Curitiba: Juruá, 2005.

CINTRA, Antônio Carlos de Araújo (Coord.); GRINOVER, Ada Pellegrini; DINAMARCO, Cândido Rangel. Teoria Geral do Processo. 20. ed. São Paulo: Malheiros, 2004.

CHIMENTI, Ricardo Cunha. Teoria e Prática dos Juizados Especiais Cíveis Estaduais e Federais. 8. ed. São Paulo: Saraiva, 2005.

COSTA, Pablo Drews Bittencourt. Uma análise crítica à Lei n. $^{\circ}$ 9.099/95. Lei dos Juizados Especiais. Jus Navigandi, Teresina, ano 6, n. 52, nov. 2001. Disponível em: <http://jus2.uol.com.br/doutrina/texto.asp?id=2394>. Acesso em: 24 set. 2006.

DIDIER, Fredie. Ação Rescisória. Aula Jurídica Virtual do Instituto de Direito-RS, do dia 09/9/2006. Disponível em: <http://www.ielf.com.br/webs/ielfnova/instituto/d.processual_civil_09_09.cfm>.

Acesso em: 23 ago. 2005

DINAMARCO, Márcia Conceição Alves. Ação Rescisória. São Paulo: Atlas, 2004.

DINAMARCO, Cândido Rangel. A Instrumentalidade do Processo. 12. ed. São Paulo: Malheiros, 2005.

FABRÍCIO, Adroaldo Furtado. A Experiência Brasileira dos Juizados de Pequenas Causas. Revista de Processo. São Paulo: Revista dos Tribunais, n. 101, jan./mar. 2001.

FERRARI, Regina Maria Macedo Nery. Normas Constitucionais Programáticas: Normatividade, Operatividade e Efetividade. São Paulo: Revista dos Tribunais, 2001.

FIGUEIRA JÚNIOR, Joel Dias; LOPES, Mauricio Antonio Ribeiro. Comentário à Lei dos Juizados Especiais Cíveis e Criminais: Lei 9.099, de 26.09.1995. 3. ed. São Paulo: Revista dos Tribunais, 2000.

FISCHER, Douglas. É Possível Ação Rescisória de Decisões Proferidas Pelos Juizados Especiais Federais. Publicação: 28/10/2005. Disponível em: <http://www.tex.pro.br/wwwroot/05de2005/epossivel_dougalsfischer.html>. Acesso em: 02 ago. 2006.

FREIRE, Rodrigo da Cunha Lima. Condições da Ação: enfoque sobre o interesse de agir. 3. ed. São Paulo: Revista dos Tribunais, 2005.

LEIRIA, Maria Lúcia Luz. Revista do Tribunal Regional Federal Quarta Região. V. 1. n. 1. Porto Alegre: O Tribunal, 1990. 
MACHADO, Antônio Cláudio da Costa. Normas Processuais Civis Interpretadas. 1. ed. São Paulo: Juarez de Oliveira, 2001.

MARINONI, Luiz Guilherme; ARENHART, Sérgio Cruz. Manual do Processo de Conhecimento. São Paulo: Revista dos Tribunais, 2001.

NEGRÃO, Theotonio; GOUVÊA, José Roberto. Código de Processo Civil e Legislação Processual em Vigor. 37. ed. Atual. Até 10 de fevereiro de 2005. São Paulo: Saraiva, 2005.

NERY JUNIOR, Nelson. Teoria Geral dos Recursos. 6. ed. São Paulo: Revista dos Tribunais, 2004-a.

NERY JUNIOR, Nelson. Princípios do Processo Civil na Constituição Federal. 8. ed. São Paulo: Revista dos tribunais, 2004-b.

NERY JUNIOR, Nelson; WAMBIER, Teresa Arruda Alvim. Aspectos Polêmicos e Atuais dos Recursos e de Outros Meios de Impugnação às Decisões Judiciais. São Paulo: Revista dos Tribunais, 2002.

NOBRE JÚNIOR, Edilson Pereira. Juizados Especiais Federais. Revista do Centro de Estudos Judiciários. Brasília: Conselho da Justiça Federal, n. 17, p. 76-89, abr./jun. 2002.

ODON, Tiago Ivo. Juizados Especiais: quando o barato sai caro. Publicação: $22 / 05 / 2005$ Disponível em: <http:/www.debater.org.br/frames/conteudos/outros/direito/juizados_especiais_quando. shtm>. Acesso em: 26 ago. 2005.

OLIVEIRA, Carlos Alberto Álvaro de; WAMBIER, Teresa Arruda Alvim (Coord.). Revista de Processo. Ano 29. N. 113. São Paulo: Revista dos Tribunais, jan-fev. 2004.

PORTANOVA, Rui. Princípios do Processo Civil. 5. ed. Porto Alegre: Livraria do Advogado, 2003.

REALE, Miguel. Filosofia do Direito. 18. ed. São Paulo: Saraiva, 1998.

ROCHA, Felippe Borring. Juizados Especiais Cíveis: aspectos polêmicos da Lei n. 9.099, de 26.09.1995. 2. ed. Rio de Janeiro: Lumen Juris, 2002.

SILVA, Ovídio Araújo Baptista da. Curso de Processo Civil. V. 1. 6. ed. São Paulo: Revista dos Tribunais, 2002.

SILVA, De Plácido e. Vocabulário Jurídico. Atualizadores: Nagib Slaibi e Gláucia Carvalho. 23. ed. Rio de Janeiro: Forense, 2003.

SOUZA, André Luís Rodrigues. Da absoluta inconstitucionalidade do art. 59 da Lei n. 9.099/95, que veda Ação Rescisória a nível de Juizados Especiais Cíveis. Publicação: 02/2001. Revista Eletrônica Mensal de Direito UNIFACS. N. 9. Disponível em: 
<http://www.unifacs.br/revistajuridica/edicao_fevereiro2001/corpodiscente/posgraduacao/inconstitucionalidade.htm>. Acesso em: 31 mar. 2006.

TEIXEIRA, Eduardo Didonet. Juizados Especiais Federais: primeiras impressões. Curitiba: Gênesis, 2001.

TESHEINER, José Maria. Eficácia da Sentença e Coisa Julgada no Processo Civil. São Paulo: Revista dos Tribunais, 2001.

TOSTES, Natacha Nascimento Gomes; CARVALHO, Márcia Cunha Silva Araújo de. Juizado Especial Cível: estudo doutrinário e interpretativo da Lei 9.099/95 e seus reflexos processuais práticos. Rio de Janeiro: Renovar, 1998.

TOURINHO NETO, Fernando da Costa; FIGUEIRA JÚNIOR, Joel Dias. Juizados Especiais Cíveis e Criminais: comentários à Lei 10.259, de 10.07.2001. São Paulo: Revista dos Tribunais, 2002.

TUCCI, José Rogério Cruz e. A Causa Petendi no Processo Civil. 2. ed. São Paulo: Revista dos Tribunais, 2001.

WAMBIER, Luiz Rodrigues (Coord.); ALMEIDA, Flávio Renato Correia de; TALAMINI, Eduardo. Curso Avançado de Processo Civil. 5. ed. São Paulo: Revista dos Tribunais, 2002. 